\title{
Effect of Particle Size on Organic Content and Microbial Abundance Within Four Marine Sediments*
}

\author{
Leon M. Cammen** \\ Marine Ecology Laboratory, Bedford Institute of Oceanography, P. O. Box 1006, Dartmouth, Nova Scotia, Canada B2Y 4A2 \\ and \\ Institute of Ecology and Genetics, University of Aarhus, DK-8000 Aarhus C, Denmark
}

\begin{abstract}
Sieved size fractions of 4 marine sediments were examined for 4 quantities presumably related to nutritional value - organic carbon, bacteria, chlorophyll $a$ and $\mathrm{C}: \mathrm{N}$ ratio of organic matter in order to determine whether they showed a consistent relation with particle size. However, there was no predictable relationship between these quantities and particle size either within or among the 4 sediments. Despite wide variations in organic carbon, bacterial abundance and chlorophyll a content, $\mathrm{C}: \mathrm{N}$ ratios were similar (near 7 ) for most of the size fractions from all 4 areas; apparently there was a large, and as yet unidentified, pool of organic carbon in these sediments other than living bacteria or microalgae with a $\mathrm{C}: \mathrm{N}$ ratio near 7 . Variation of microbial abundance between winter and summer was inconsistent, but bacteria always accounted for less than $2 \%$ of the organic carbon in the sediment. This study emphasizes the difficulty in attempting to predict nutritional value of sediments from bulk samples.
\end{abstract}

\section{INTRODUCTION}

Previous investigations have shown an inverse relationship between the particle size of marine sediments and various measures of 'nutritional quality' such as organic matter concentration or bacterial abundance (Longbottom, 1970; Hargrave, 1972; Dale, 1974). From these studies the general perception has arisen that fine-grained sediments are richer food sources for deposit feeders than are coarse-grained sediments. This assumption has been utilized to model optimal deposit feeding behavior, particularly in respect to particle selection (e.g. Taghon et al., 1978). However, with the exception of some observations by Lopez and Levinton (1978), these studies have compared particle size and 'nutritional quality' only among sediments from different areas and utilized measurements made on bulk sediment samples. Since deposit feeders that select particles do so from within a single sediment, it is actually the within-sediment variation of 'nutritional

\footnotetext{
- Bigelow Laboratory for Ocean Sciences Contribution No. 82003

- Present address: Bigelow Laboratory for Ocean Sciences, McKown Point, West Boothbay Harbor, Maine 04575, USA

(C) Inter-Research/Printed in F. R. Germany
}

quality' with particle size that is important, not amongsediments variation; there is no a priori reason that the within-sediment variation should be the same as that found in comparisons of bulk sediment samples. The nature of the within-sediment variation is of fundamental importance to consideration of deposit feeding behavior so I have attempted to test whether 'food quality' varies in some predictable way with particle size within 4 marine sediments and whether the relationship is consistent among the 4 sediments throughout the year. The 4 sediments were taken from both intertidal and subtidal areas in winter and summer; 'food quality' was measured as organic carbon concentration, $\mathrm{C}: \mathrm{N}$ ratio, bacterial abundance and chlorophyll a concentration.

\section{METHODS AND MATERIALS}

\section{Study Sites}

Four locations were sampled on 2 occasions during this study. One, Peck's Cove, was an intertidal mudflat lacated in eastern Canada. The others, Lendrup 
Strand, Kalø Pond and Kysing Fjord, were subtidal areas in Denmark. The following are brief descriptions of these sites:

Peck's Cove is a $1 \mathrm{~km}$-wide mudflat located at the mouth of Cumberland Basin in the upper Bay of Fundy. Tidal range in this area averages $11 \mathrm{~m}$ and the study site was submerged under an average of $3 \mathrm{~m}$ at high tide; the site was exposed an average of $16 \mathrm{~h} \mathrm{~d}^{-1}$. The most abundant macrofauna in this area were the amphipod Corophium volutator, the polychaete Heteromastus filiformis, and the snail Hydrobia minuta; there was also an abundant population of the bivalve Macoma balthica less than $100 \mathrm{~m}$ from the site. The uppermost portion of the mudflat supported a narrow band of Spartina alterniflora marsh and diatoms were visibly abundant on the sediment surface of the entire mudflat. Samples were taken from the upper portion of the mudflat on 1 June and 12 October 1979. Although no data was available on the water flooding the study site on those days, on 11 June water temperature at high tide was $12.3^{\circ} \mathrm{C}$ and salinity was $25.4 \% \mathrm{~S}$; on 5 October at high tide water temperature was $14.0^{\circ} \mathrm{C}$ and salinity was $26.8 \% \mathrm{~S}$.

Lendrup Strand study site was a small pond located in the Limfjord about $5 \mathrm{~km}$ from Rønbjerg. Tidal amplitude is quite small (as with the other 2 Danish sites) with wind being more important than tides in affecting water depth. The pond was fairly shallow with a depth of about $20 \mathrm{~cm}$ in the area I sampled. Corophium volutator, Hydrobia spp. and the bivalve Mya arenaria are ordinarily abundant in this pond (T. Fenchel, pers. comm.), but very few $C$. volutator were observed during this study. The eelgrass Zostera marina was abundant. The samples were taken on $6 \mathrm{March}$ (water temperature $1^{\circ} \mathrm{C}$, salinity $0 \% \mathrm{~S}$ ) and 28 August $1980\left(17^{\circ} \mathrm{C}, 24.4 \%\right.$ S $)$

$\mathrm{K}$ a $l ø \mathrm{P}$ on $\mathrm{d}$ is another small, shallow pond located about $30 \mathrm{~km}$ east of Aarhus. As at Lendrup Strand, the tidal effect is virtually non-existent; water depth was less than $1 \mathrm{~m}$ throughout the pond and about $20 \mathrm{~cm}$ in the area I sampled. Macrofauna were not as abundant in this location as in the 3 other areas, but some Nereis sp., insect larvae and Corophium volutator were present. The pond was surrounded by marsh vegetation and Zostera marina was abundant; in addition, white and purple sulfur bacteria were present on the sediment surface. This area was sampled 11 March $\left(4^{\circ} \mathrm{C}\right.$, $2.5 \% \mathrm{~S})$ and 25 August $\left(14.5^{\circ} \mathrm{C}, 26 \% \mathrm{~S}\right)$.

Kysing F jord is a shallow estuary located about $20 \mathrm{~km}$ south of Aarhus. It is about $3 \mathrm{~km}$ long with an area of about $2 \mathrm{~km}^{2}$ and is also subject mainly to windgenerated variations in water level. Corophium volutator, Hydrobia spp. and Nereis spp. were all abundant. There were extensive Zostera marina beds in the estuary with a sizeable population of the mussel
Mytilus edulis. Samples were taken on 14 February $\left(-0.3^{\circ} \mathrm{C}, 21.7 \% \mathrm{~S}\right)$ and 21 August $\left(15^{\circ} \mathrm{C}, 20 \% \mathrm{~S}\right)$.

\section{Sample Collection and Treatment}

Sediment samples were taken from each of these areas by gently scraping the surface with a spatula. For the subtidal sites, a shovel was used to bring the top 5 to $10 \mathrm{~cm}$ of sediment carefully out of the water prior to scraping the surface. Only the top 1 to $2 \mathrm{~mm}$ was sampled; for example, the 14 February sample from Kysing Fjord resulted in $25 \mathrm{~cm}^{3}$ of sediment from an area of $340 \mathrm{~cm}^{2}$, representing an average depth of about $0.75 \mathrm{~mm}$, ignoring any compaction which may have occurred.

A subsample of each of these samples was gently wet-sieved through a series of Nitex mesh sieves $(243$, $202,153,102,67,41,30,20$, and $10 \mu \mathrm{m}$ ) to give 10 size fractions. For the Peck's Cove samples, 4 to $5 \mathrm{~g}$ wet weight was sieved at one time, but for the Danish samples, which were coarser sediment, it was necessary to sieve $25 \mathrm{~cm}^{3}$ in order to abtain sufficient amounts of the fine fractions. Sieving was done with a gentle shaking action for all except the $10-\mu \mathrm{m}$ sieve which required a vacuum; the entire procedure was carried out with $0.2-\mu \mathrm{m}$ filtered seawater. The fractions were rinsed from the sieves onto $0.2-$ or $0.45-\mu \mathrm{m}$ filters and the sediment scraped off with a spatula. Portions of each fraction were analyzed for bacteria, chlorophyll a and phaeopigments, and both Peck's Cove samples and the August samples from the Danish stations were analyzed for carbon and nitrogen; it was necessary to use two or three subsamples, each sieved separately, to obtain enough material for all the analyses. The samples were refrigerated until sieving which was within 1 $d$ of collection for the bacteria and pigment analyses and within $2 \mathrm{~d}$ for the carbon and nitrogen analyses. Macrofauna were removed from the $>243-\mu \mathrm{m}$ fraction prior to the analyses, but mesofauna (= meiofauna) were not excluded.

Bacteria were counted at $1250 \mathrm{X}$ using epifluorescent microscopy and acridine orange (Rublee and Dornseif, 1978). Average cell sizes were determined for each of the size fractions from the June Peck's Cove samples by observing 100 cells and placing them in 1 of 7 categories: cocci $\leq 0.5 \mu \mathrm{m}$ in diameter (assumed volume of $\left.0.065 \mu^{3}\right)$ and 0.5 to $1.0 \mu \mathrm{m}\left(0.524 \mu^{3}\right)$; rods $\leq 0.5 \mu \mathrm{m}$ in length $\left(0.035 \mu \mathrm{m}^{3}\right), 0.5$ to $1.0 \mu \mathrm{m}$ $\left(0.126 \mu \mathrm{m}^{3}\right), 1.0$ to $1.5 \mu \mathrm{m}\left(0.188 \mu \mathrm{m}^{3}\right)$ and 1.5 to $2.0 \mu \mathrm{m}$ $\left(0.251 \mu \mathrm{m}^{3}\right)$; volumes were calculated individually for other cells. For the samples other than Peck's Cove, an average cell volume of $0.2 \mu \mathrm{m}^{3}$ was assumed (Rublee, in press). Biomass was estimated from cell volume by assuming a cell density of $1.1 \mathrm{~g} \mathrm{~cm}^{-3}$, a dry : wet 
weight ratio of 0.23 and a carbon content of 0.344 (following Ferguson and Rublee, 1976).

Pigment analyses were carried out fluorometrically on the Peck's Cove samples with acetone extraction (Lorenzen, 1967) and spectrophotometrically on the Danish samples with methanol extraction (Holm-Hansen and Riemann, 1978). Fluorometry may sometimes overestimate chlorophyll a (Brown et al., 1981), but there is no information to indicate whether or not there would be consistent error among various size fractions of the same sediment. Microalgal carbon was estimated by assuming a $\mathrm{C}$ : chl ratio of 40 from de Jonge (1980); this was the overall mean factor for two of the three years he sampled.

Carbon and nitrogen analyses were carried out with a Perkin-Elmer Model 240 B Elemental Analyzer following acidification of the sediment with $10 \% \mathrm{HCl}$.

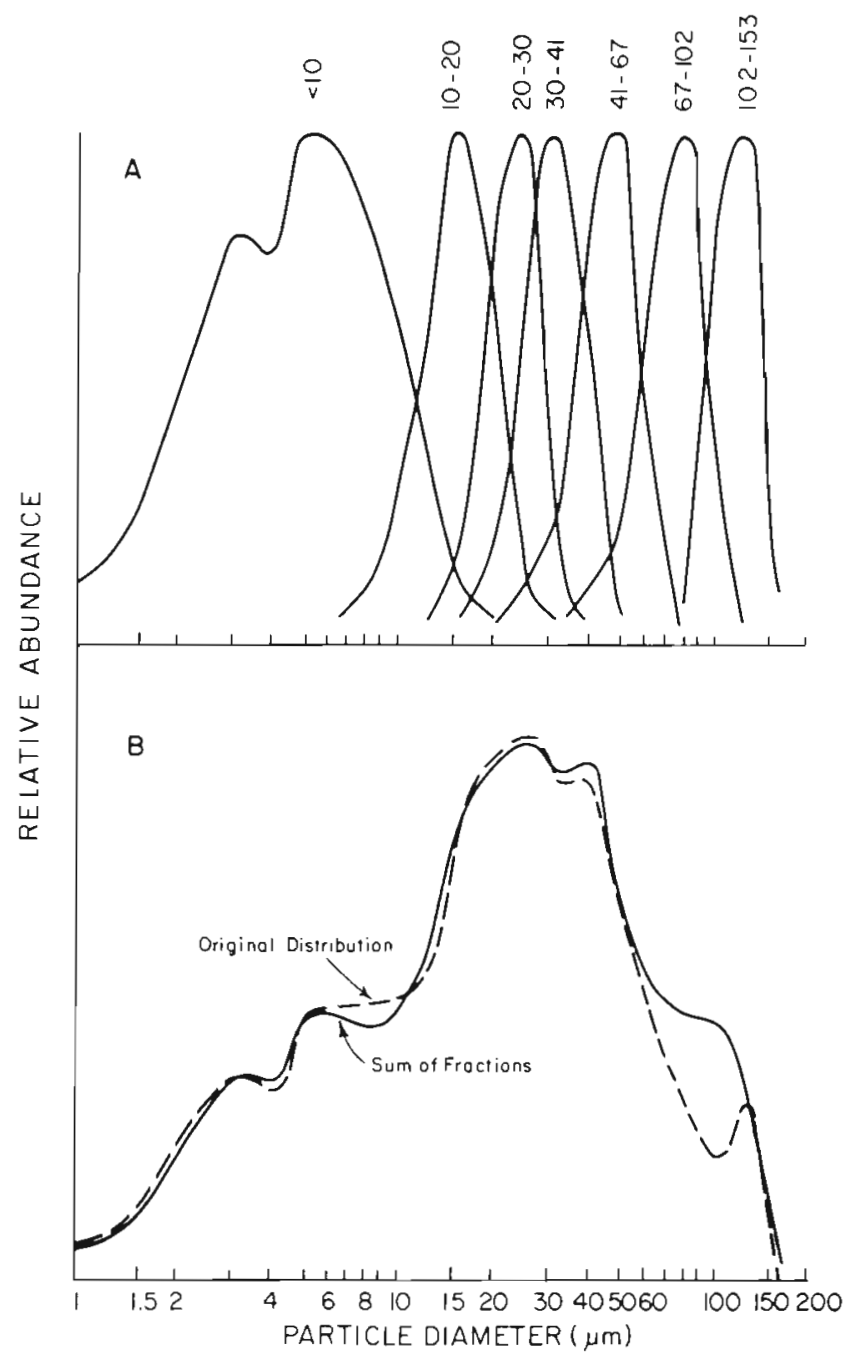

Fig. 1 (A) Relative distribution of sediment particles within each sieve fraction as determined by Coulter Counter. (B) Comparison of distribution before sieving with sum of sieved size fractions
Since the sieving procedure involved manipulation of the sediment and required several hours to complete, I tested the Peck's Cove samples to see if either the particle size distribution or the abundance of bacteria was effected. With a Model TA II Coulter Counter, I first determined that the sieves did give a good separation of the size fractions $<153 \mu \mathrm{m}$ (Fig. 1). Then by summing the distributions of all size fractions $<153 \mu \mathrm{m}$, the original distribution was estimated and compared with the distribution of a sample of the same sediment which had not been sieved (Fig. 1); the close agreement of these 2 distributions shows that the sieving procedure did not result in either significant breakdown of large particles or aggregation of small particles. With the same procedure, the bacterial counts in each fraction were used to generate an estimate of the bacteria per $\mathrm{g}$ in the original sample and compared with a count of the original sample. These counts were as follows: 1 June - original sample, (2 replicates) 5.2 and $6.0 \times 10^{9} \mathrm{~g}^{-1}$ dry weight; sieved total, $7.2 \times 10^{9} \mathrm{~g}^{-1} ; 12$ October - original sample, $5.1 \times 10^{9} \mathrm{~g}^{-1}$; sieved total, $5.0 \times 10^{9} \mathrm{~g}^{-1}$. Again, the close agreement indicates that there was not a substantial change during sieving

\section{RESULTS}

The 4 areas sampled included a wide range of particle sizes and organic matter contents (Fig. 2, Table 1). Particle size by itself did not indicate much about the overall nutritional value of the sediments; for example, both Kalø Pond and Kysing Fjord had the same modal particle size but differed in bacteria numbers, chlorophyll $a$, organic carbon and nitrogen by 1 to 2 orders of magnitude. Carbon : nitrogen ratios were similar for all 4 sediments and averaged about 7 .

Bacteria accounted for less than $2 \%$ of the total organic carbon in each of the size fractions of the summer samples, but as much as $71 \%$ of the organic carbon was due to microalgae (Fig. 3). With the exception of the October Peck's Cove sample, there was relatively little variation in the percentage microbial carbon made up to total organic carbon in the fractions less than $243 \mu \mathrm{m}$, despite the large variations in absolute amounts of both microbial and total organic carbon (Figs. 4 to 7 ).

Peck's Cove (Fig. 4). There was no consistent relation between particle size and any of the measures of nutritional value (bacteria, chlorophyll $a$ and organic $\mathrm{C}$ per $\mathrm{g}$ dry sediment and $\mathrm{C}: \mathrm{N}$ ratio) in either the June or October samples. Although the concentration of bacteria was highest in the $<10-\mu$ m fraction and declined until the 41 to $67-\mu \mathrm{m}$ fraction, there was a 


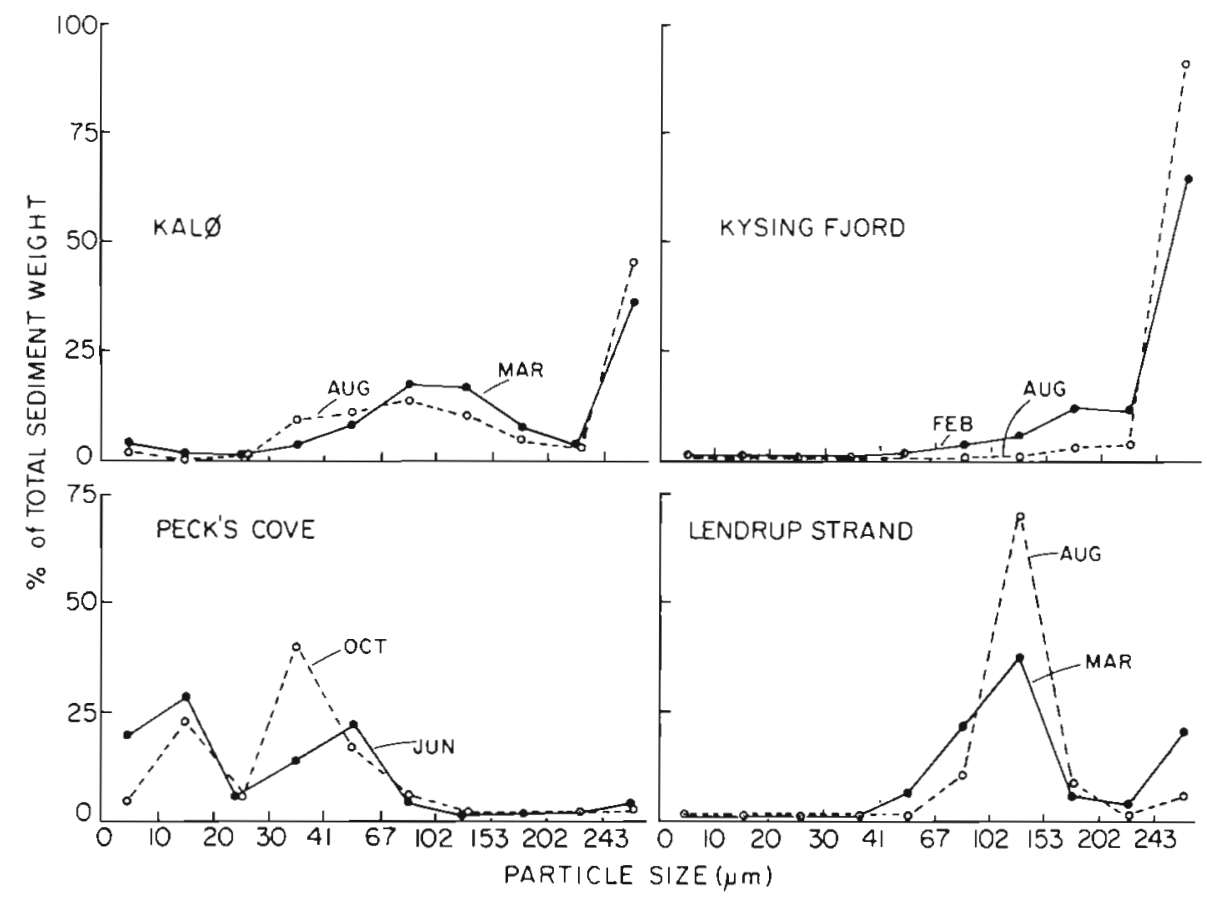

Fig. 2. Particle size distributions of sediment samples second peak in concentration for particles between 102 and $243 \mu \mathrm{m}$ in size. Bacterial cell volume varied between 0.10 and $0.14 \mu \mathrm{m}^{3}$ for the various fractions and there was no relation between cell volume and particle size. The percent organic carbon followed virtually the same pattern although the larger particles had nearly twice the concentration of organic carbon as the < $10-\mu \mathrm{m}$ fraction. Microalgae (as measured by chlorophyll a) reached their greatest concentration in the 102 to $153-\mu \mathrm{m}$ fraction in both samples; actual concentration was much greater in October. $\mathrm{C}: \mathrm{N}$ ratios were fairly consistent, between 5 and 7.6 for all fractions in the June sample.

Le ndrup Strand (Fig. 5). There was a decrease in bacteria, chlorophyll $\boldsymbol{a}$ and organic carbon concentrations with particle size in both samples from the $<10-\mu m$ fraction to the 102 to $153-\mu \mathrm{m}$ fraction; concentrations were similar for particles from 102 to $243-\mu \mathrm{m}$.
$\mathrm{C}: \mathrm{N}$ ratios were similar for all fractions, ranging from 6.2 to 7.5 . Both bacteria and chlorophyll a were generally more abundant in March than in August.

$\mathrm{Ka} l ø$ Pond (Fig. 6). Both bacteria and chlorophyll a concentrations fluctuated for size fractions less than $41 \mu \mathrm{m}$, but decreased fairly regularly for larger particles. The organic carbon concentration decreased with increased particle size while the $C: N$ ratio was between 6.2 and 6.9 for all size fractions except the largest. Bacteria were more abundant in August than in March, but chlorophyll a concentrations were generally similar.

Kysing Fjord (Fig. 7). There was a general, regular decrease of bacteria, chlorophyll a and organic carbon concentrations with particle size in both samples. The $\mathrm{C}: \mathrm{N}$ ratio also decreased slowly with particle size, from 7.9 in the $<10-\mu \mathrm{m}$ fraction to 5.7 to 6.1 in the 202 to 243 - and $>243-\mu$ fractions. Bacteria were

Table 1. Overall values for sediment samples (without size fractionation)

\begin{tabular}{|c|c|c|c|c|c|c|}
\hline Area & Month & $\begin{array}{l}\text { Modal particle } \\
\text { size }(\mu \mathrm{m})\end{array}$ & $\begin{array}{c}\text { Bacteria } \\
\left(g^{-1}\right)\end{array}$ & $\begin{array}{c}C h l a \\
\left(\mu g^{-1}\right)\end{array}$ & $\begin{array}{c}\text { Organic C } \\
(\%)\end{array}$ & $C: N$ \\
\hline Kalø & Aug & $>243$ & $1.0 \times 10^{11}$ & 249.1 & 15.5 & 7.69 \\
\hline Pond & Mar & $>243$ & $6.4 \times 10^{10}$ & 242.2 & - & - \\
\hline Kysing & Aug & $>243$ & $2.0 \times 10^{9}$ & 16.0 & 0.242 & 6.67 \\
\hline Fjord & Feb & $>243$ & $1.7 \times 10^{9}$ & 19.1 & - & - \\
\hline Lendrup & Aug & $102-153$ & $2.9 \times 10^{9}$ & 26.5 & 0.451 & 6.67 \\
\hline Strand & Mar & $102-153$ & $6.3 \times 10^{9}$ & 88.9 & - & - \\
\hline Peck's & Jun & $10-20$ & $7.2 \times 10^{9}$ & 9.2 & 0.687 & 6.33 \\
\hline Cove & Oct & $30-41$ & $5.0 \times 10^{9}$ & 66.5 & 0.699 & - \\
\hline
\end{tabular}




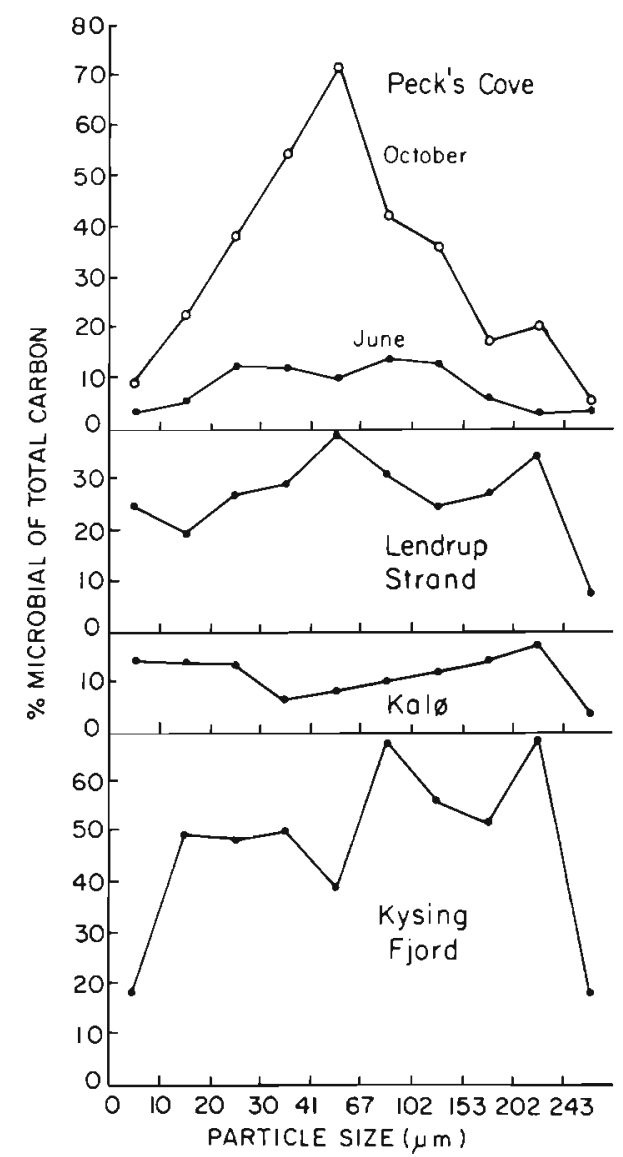

Fig. 3. Percentage of total sediment organic carbon accounted for by bacteria and microalgae. See text for conversion factors

more abundant in August than in March for the fractions less than $30 \mu \mathrm{m}$, but were similar in numbers for larger particles. Chlorophyll a was much more abundant in August than in March for all but the $>243-\mu \mathrm{m}$ fraction

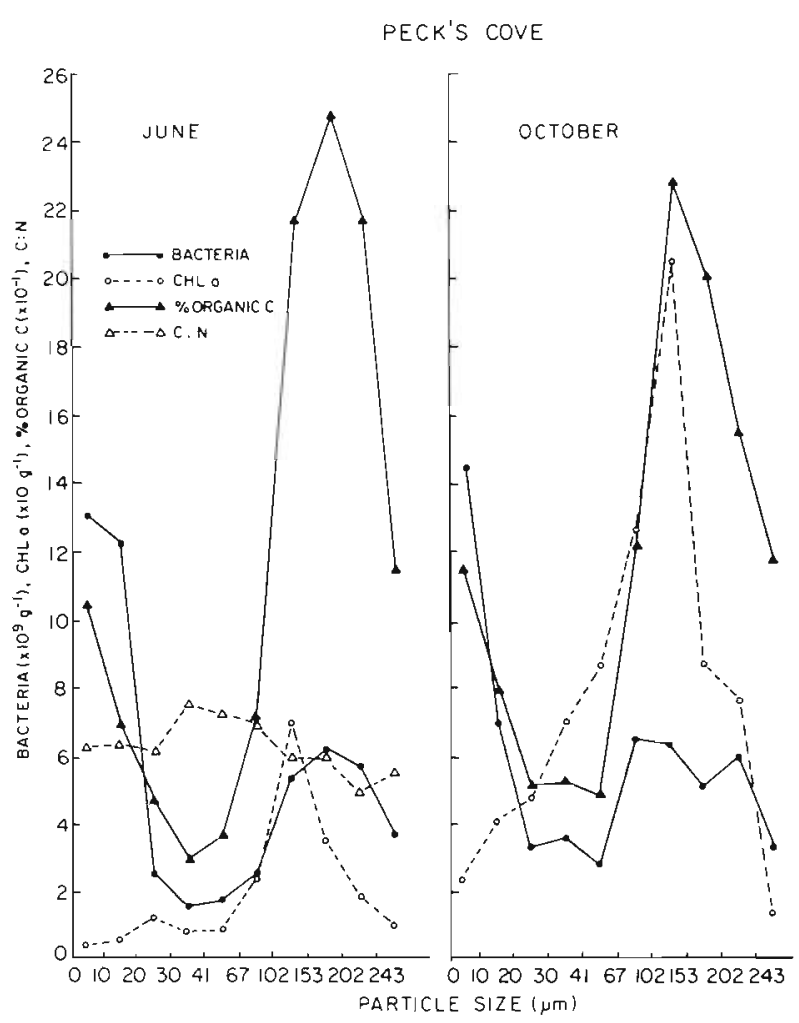

Fig. 4. Bacteria and chl $a \mathrm{~g}^{-1}, \%$ organic carbon and $\mathrm{C}: \mathrm{N}$ ratio for sediment fractions from Peck's Cove

\section{DISCUSSION}

There was little indication of any change in the 'quality' of the organic matter with particle size in these samples. In general, both the percentage of the
Fig. 5. Bacteria and chl a $\mathrm{g}^{-1}, \%$ organic carbon and $\mathrm{C}: \mathrm{N}$ ratio for sediment fractions from Lendrup Strand. Note that bacteria, chl $a$, and \% organic carbon scales are compressed $10 \times$ from Fig. 3

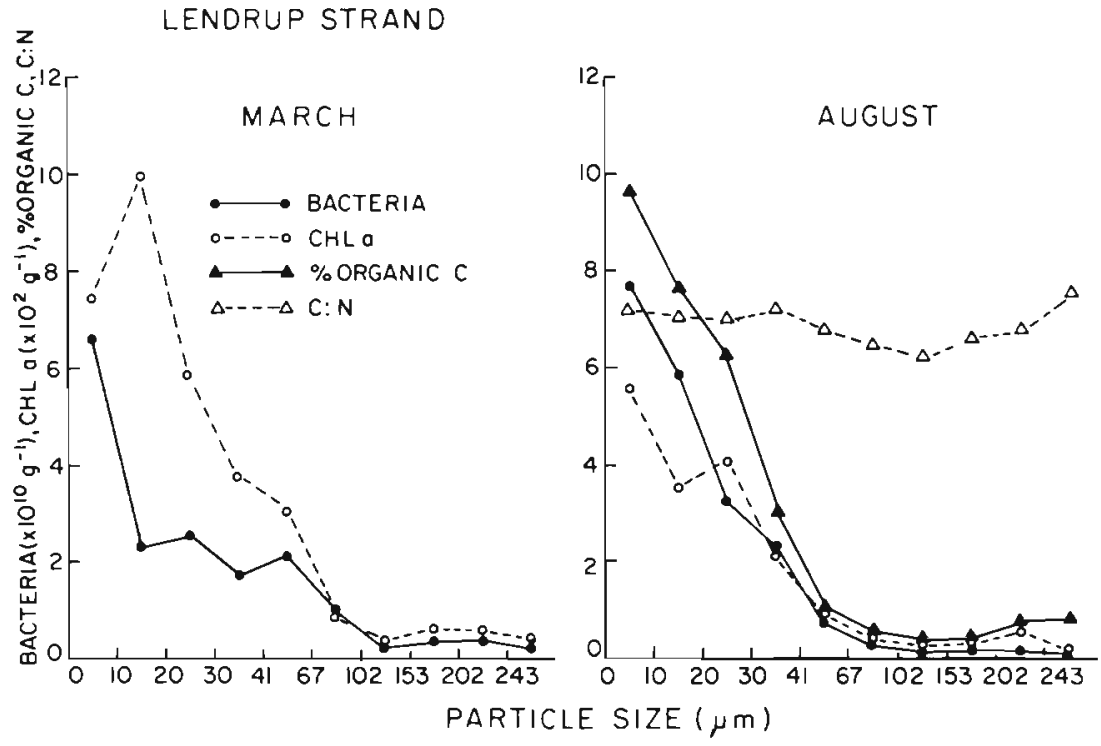




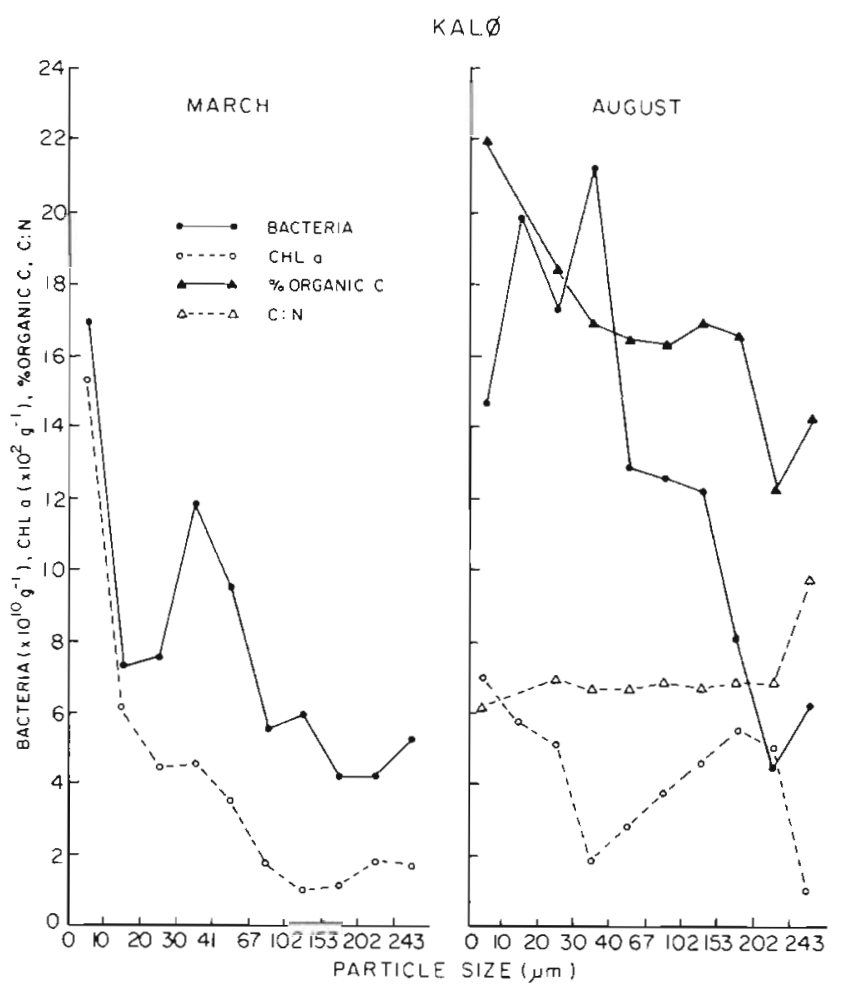

Fig. 6. Same as Fig. 5 for Kalø Pond

total organic carbon accounted for by microbes and the $C: N$ ratio of the organic matter were similar for most particle sizes within each sample; as noted previously, the October Peck's Cove sample and the $>243-\mu \mathrm{m}$ fractions of the other samples were exceptions. Of course, $\mathrm{C}: \mathrm{N}$ ratios are only a general indicator of the food value of the organic matter, but values as low as 7 suggest that the organic matter may be suitable for deposit feeding organisms (Russell-Hunter, 1970). Ratios in this range have been found in previous studies where either terrestrial soils (Cameron and Posner, 1979; Turchenek and Oades, 1979) or aquatic sediments (Thompson and Eglinton, 1978; Tanoue and Handa, 1979) were fractionated; even lower values (2 to 6) have been reported for bulk samples of deep-sea sediments (Müller, 1977) while some near-shore surface sediments had values between 3 and 25 with about $40 \%$ of the samples between 5.5 and 8.5 (Bader, 1955). The composition of most of the organic matter from the sediments sampled during this study is unknown, but assuming a $\mathrm{C}: \mathrm{N}$ ratio of 3.5 for bacteria (R. L. Ferguson, unpub. data from 8 estuarine bacteria species) and 5.5 to 7.5 for microalgae (various sources cited in Müller, 1977, for diatoms) and taking into account the abundance of microbial carbon, we can estimate the range of possible $\mathrm{C}$ : $\mathrm{N}$ ratios for the nonmicrobial organic matter. In general, the estimated $\mathrm{C}: \mathrm{N}$ ratios for non-microbial organic matter were between 5 and 8 with the highest value only 11.0 (Table 2). These values are low in comparison with C : N ratios of decomposing macrophytes (Mann, 1972), even for the Kalø Pond > 243- $\mu \mathrm{m}$ fraction which contained numerous seagrass fragments. Thus, there appears to be an abundant, unidentified pool of organic matter with a $\mathrm{C}: \mathrm{N}$ ratio between 5 and 8 which may be a significant source of food to detritivores and deposit feeders. Although it is difficult to speculate as to the nature of this pool, Hobbie and Lee (1980) have proposed that mucopolysaccharides may be abundant in sediments and at least 1 of these compounds (chitin) has a $\mathrm{C}: \mathrm{N}$ ratio of about 7 . These compounds may be produced by bacteria (Hobbie and Lee, 1980) and benthic microalgae (Holland et al.,

KYSING FJORD

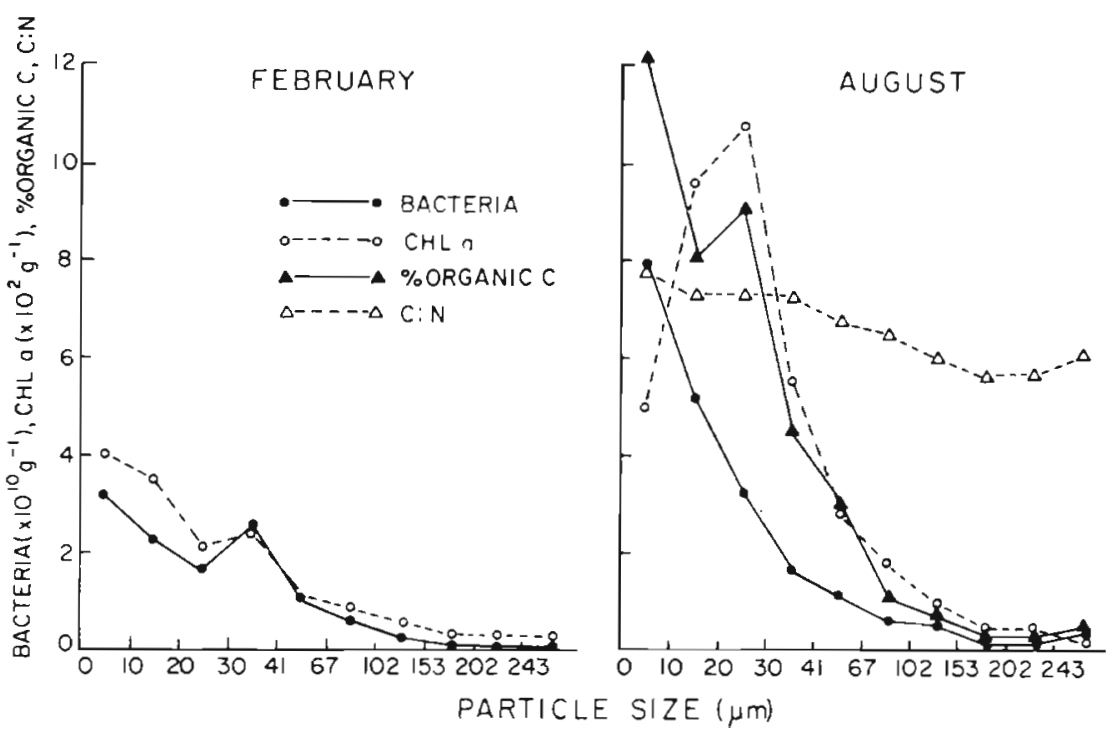

Fig. 7. Same as Fig. 5 for Kysing Fjord 
Table 2. Calculated $\mathrm{C}: \mathrm{N}$ ratios for the portion of organic matter in summer sediment samples not accounted for by either bacteria or microalgae. Overall values were calculated from data in Table 1 . These calculations assume $\mathrm{C}: \mathrm{N}$ ratios of 3.5 for bacteria and either 5.5 or 7.5 (as indicated) for microalgae

\begin{tabular}{|c|c|c|c|c|c|c|c|c|}
\hline \multirow{2}{*}{$\begin{array}{l}\text { Size } \\
\text { fraction }(\mu \mathrm{m})\end{array}$} & \multicolumn{2}{|c|}{ Kalø Pond } & \multicolumn{2}{|c|}{ Kysing Fjord } & \multicolumn{2}{|c|}{ Lendrup Strand } & \multicolumn{2}{|c|}{ Peck's Cove } \\
\hline & 5.5 & 7.5 & 5.5 & 7.5 & 5.5 & 7.5 & 5.5 & 7.5 \\
\hline$<10$ & 6.3 & 6.0 & 8.8 & 8.1 & 8.0 & 7.2 & 6.3 & 6.3 \\
\hline $10-20$ & - & - & 11.0 & 7.3 & 7.6 & 7.0 & 6.4 & 6.3 \\
\hline $20-30$ & 7.3 & 7.0 & 10.7 & 7.3 & 7.9 & 6.9 & 6.3 & 6.0 \\
\hline $30-41$ & 6.9 & 6.8 & 10.7 & 7.1 & 8.4 & 7.2 & 8.0 & 7.6 \\
\hline $41-67$ & 6.9 & 6.7 & 8.0 & 6.5 & 8.2 & 6.5 & 7.6 & 7.3 \\
\hline $67-102$ & 7.1 & 6.9 & 11.0 & 5.2 & 7.2 & 6.2 & 7.4 & 7.0 \\
\hline $102-153$ & 7.0 & 6.7 & 7.1 & 5.0 & 6.5 & 5.9 & 6.1 & 5.8 \\
\hline $153-202$ & 7.2 & 6.8 & 6.0 & 4.6 & 7.2 & 6.4 & 6.1 & 6.0 \\
\hline $202-243$ & 7.2 & 6.7 & 6.2 & 3.7 & 7.8 & 6.4 & 4.9 & 4.9 \\
\hline$>243$ & 10.1 & 10.0 & 6.3 & 5.9 & 7.8 & 7.6 & 5.6 & 5.5 \\
\hline Overall & 8.0 & 7.8 & 7.4 & 6.5 & 7.2 & 6.5 & 6.5 & 6.4 \\
\hline
\end{tabular}

1974; Darley, 1977) and even by animals dwelling in the sediment (Riemann and Schrage, 1978). It is thus possible that although only a small fraction of the organic matter is in the form of living microbes, a relatively large fraction may be microbially-derived. On the other hand, much of the nitrogen may be present as resistant complexes such as protein-lignin, phenol-protein, protein-chitin, and inorganic clayamino groups or as nitrogen-containing humic acids (Odum et al., 1979; D. L. Rice, pers. comm.). The difference between these 2 possibilities is significant since the organic complexes are refractory and may not be available to animal consumers (Odum et al., 1979) while microbially-derived organic matter may be a nutritious food source. A number of detritivores and deposit feeders have shown some ability to digest mucopolysaccharides (Elyakova, 1972; Kristensen, 1972; Jennings and Deutsch, 1975).

In the 3 areas sampled in winter and summer, Kalo Pond, Lendrup Strand and Kysing Fjord (Figs. 5 to 7 ), the variation of bacterial and microalgal populations between seasons was inconsistent. Most of the size fractions from Kalø Pond and Kysing Fjord had greater concentrations of microbes in summer than in winter, but the reverse was true for Lendrup Strand. Although no attempt was made to estimate predation rates on the microbes or microbial growth rates, winter water temperatures were so low $\left(-0.3\right.$ to $\left.4^{\circ} \mathrm{C}\right)$ in comparison to summer $\left(14.5\right.$ to $\left.17^{\circ} \mathrm{C}\right)$ that probably both predation and growth were much lower in the winter. The data in this study are all standing stocks and as such represent the equilibria resulting from predation on the microbes and their growth. There was no general trend for seasonal variation in these equilibria.

The data from this study indicate that any generalization of the relation between bacterial concentration and particle size must be made with caution. Both the among-sediment data (Table 1) and the within-sediment data (Figs. 4 to 7 ) show that there can be (and often are) more bacteria associated with larger particles than with small. It appears that variation in organic content is more important than particle size in determining bacterial abundance. Rublee (in press) summarized a large number of studies and found a significant correlation between bacterial abundance and sediment organic carbon; he suggested that this is a causal relationship resulting from microbial metabolism of the organic carbon. An additional explanation is that since organic matter is less dense than mineral grains, an increase in organic matter also means an increase in both number and total surface area of particles for a given weight of a sediment size fraction; previous studies have shown that bacterial abundance is positively correlated with available surface area (summarized in Rublee and Dornseif, 1978).

Many animals are able to feed selectively on sediment and ingest only a limited range of particle sizes and for these organisms it would be difficult, if not useless, to attempt to assess nutritional quality of the sediment with bulk sediment analyses. For example, Kysing Fjord sediment in August would appear to be relatively poor in microalgae (16 $\mu \mathrm{g} \mathrm{chl} \mathrm{a} \mathrm{g}^{-1}$ ) if only a sample of the whole sediment were analyzed. If we look at only the fraction utilized by a hypothetical deposit feeder tending to select particles between 20 and $41 \mu \mathrm{m}$, then the sediment would appear relatively rich $\left(907 \mu \mathrm{g} \mathrm{chl} \mathrm{g} \mathrm{g}^{-1}\right)$. An additional illustration is that in comparison to the October sample from Peck's Cove, the Kysing Fjord sediment is much poorer on a bulk basis (16 compared with $67 \mu \mathrm{g}$ chl $\mathrm{a} \mathrm{g}^{-1}$ ), but much richer in the fraction utilized by our hypothetical

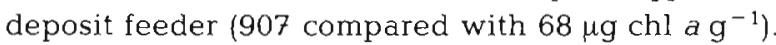


Acknowledgements. I thank Judy Walker for her aid in the Canadian portion of this study as well as the other members of the Peck's Cove ecosystem project. The $\mathrm{CN}$ analyses were carried out at Skidaway Institute of Oceanography, Savannah, Georgia, USA. Reviews by Donald Gordon and Jeffrey Levinton improved the manuscript. I am grateful to Donald Gordon, Barry Hargrave and Tom Fenchel for the opportunity to visit and work at their laboratories. Support for this project was from a National Research Council Canada Visiting Fellowship and a NATO Post-doctoral Fellowship.

\section{LITERATURE CITED}

Bader, R. G. (1955). Carbon and nitrogen relations in surface and subsurface marine sediments. Geochim. cosmochim. Acta 7: 205-211

Brown, L. M., Hargrave, B. T., Mackinnon, M. D. (1981). Analysis of chlorophyll a in sediments by high-pressure liquid chromatography. Can. J. Fish. Aquat. Sci. 38: 204-214

Cameron, R. S., Posner, A. M. (1979). Mineralisable organic nitrogen in soil fractionated according to particle size. $J$ Soil Sci. 30: 565-577

Dale, N. G. (1974). Bacteria in intertidal sediments: factors related to their distribution. Limnol. Oceanogr. 19: 509-518

Darley, W. M. (1977). Biochemical composition. In: Werner, D. (ed.) The biology of diatoms. University of California Press, Berkeley, pp. 198-223

Elyakova, L. A. (1972). Distribution of cellulases and chitinases in marine invertebrates. Comp. Biochem. Physiol. 43B: $67-70$

Ferguson, R. L., Rublee, P. (1976). Contribution of bacteria to standing crop of coastal plankton. Limnol. Oceanogr. 21: 141-145

Hargrave, B. T. (1972). Aerobic decomposition of sediment and detritus as a function of particle surface area and organic content. Limnol. Oceanogr. 17: 583-596

Hobbie, J. E., Lee, C. (1980). Microbial production of extracellular material: importance in benthic ecology. In: Tenore, K. R., Coull, B. C. (eds.) Marine benthic dynamics. University of South Carolina Press, Columbia, pp. 341-346

Holland, A. F., Zingmark, R. G., Dean, J. M. (1974). Quantitative evidence conceming the stabilization of sediments by marine benthic diatorns. Mar. Biol. 27: 191-196

Holm-Hansen, O, Riemann, B. (1978). Chlorophyll a determination: improvements in methodology. Oikos 30: 438-447

Jennings, J. B., Deutsch, A. (1975). Occurrence and possible adaptive significance of $B$-glucuronidase and arylamidase (leucine aminopeptidase) activity in two species of marine nematodes. Comp. Biochem. Physiol. 52A: 611-614
Jonge, V. N. de (1980). Fluctuations in the organic carbon to chlorophyll a ratios for estuarine benthic diatom populations. Mar, Ecol, Prog. Ser. 2: 345-353

Kristensen, J. H. (1972). Carbohydrases of some marine invertebrates with notes on their food and on the natural occurrence of the carbohydrates studied. Mar. Biol. 14: $130-142$

Longbottom, M. R. (1970). The distribution of Arenicola marina (L.) with particular reference to the effects of particle size and organic matter of the sediments. J. exp. mar. Biol. Ecol. 5; 138-157

Lopez, G. R., Levinton, J. S. (1978). The availability of microorganisms attached to sediment particles as food for $\mathrm{Hyd}$ robia ventrosa Montagu (Gastropoda: Prosobranchia). Oecologia 32: 263-275

Lorenzen, C. J. (1967). Determination of chlorophyll and phaeopigments: spectrophotometric equations. Limnol. Oceanogr. 12: 343-346

Mann, K. H. (1972). Macrophyte production and detritus food chains in coastal waters. In: Melchiorri-Santolini, U., Hopton, J. W. (eds.) Detritus and its role in aquatic ecosystems. Memorie Ist. ital. Idrobiol. 29 (Suppl.): 353-383

Müller, P. J. (1977). C/N ratios in Pacific deep-sea sediments: effect of inorganic ammonium and organic nitrogen compounds sorbed by clays. Geochim. Cosmochim. Acta 41 : $765-776$

Odum, W. E., Kirk, P. W., Zieman, J. C. (1979). Non-protein nitrogen compounds associated with particles of vascular plant detritus. Oikos 32: 363-367

Riemann, F., Schrage, M. (1978). The mucus-trap hypothesis on feeding of aquatic nematodes and implications for biodegradation and sediment texture. Oecologia 34: $75-88$

Rublee, P. A. (In press). Bacteria and microbial distribution in estuarine sediments. In: Kennedy, V. S. (ed.) Estuarine comparisons. Academic Press, New York

Rublee, P. A., Dornseif, B. E. (1978). Direct counts of bacteria on the sediments of a North Carolina salt marsh. Estuaries 1: $188-191$

Russell-Hunter, W. D. (1970). Aquatic productivity, MacMillan, New York

Taghon, G. L., Self, R. F. L., Jumars, P. A. (1978). Predicting particle selection by deposit feeders: a model and its implications. Limnol. Oceanogr. 23: 752-759

Tanoue, E., Handa, N. (1979). Differential sorption of organic matter by various sized sediment particles in recent sediment from the Bering Sea. J. oceanogr. Soc. Japan 35: $199-208$

Thompson, S., Eglinton, G. (1978). The fractionation of a recent sediment for organic geochemical analysis. Geochim. cosmochim. Acta 42: 199-207

Turchenek, L. W., Oades, J. M. (1979). Fractionation of organo-mineral complexes by sedimentation and density techniques. Geoderma 21: 311-343 